\title{
Viaje y nación en la literatura mexicana (1836-1871). Tres casos: Carpio, Altamirano y México y sus alrededores
}

\author{
Travel and Nation in Mexican Literature (1836-1871). \\ Three Cases: Carpio, Altamirano and México \\ y sus alrededores
}

\author{
Gerardo Francisco Bobadilla Encinas \\ Universidad de Sonora \\ gbobadil@capomo.uson.mx
}

RESUMEN: Diversas manifestaciones de la literatura mexicana del siglo XIX articularon una serie de resoluciones éticas y estéticas, que contribuyeron en la definición y consolidación de un imaginario colectivo en torno al hombre y la naturaleza propios. Se buscaba, así, dar sentido y trascendencia cultural al proyecto de nación que entonces surgía.

Como se plantea en este trabajo, el motivo literario del viaje y su perspectiva fueron los detonantes a partir de los que se configuró ese imaginario cultural sobre el cual se concreta y cobra significado el concepto y la imagen de lo mexicano, como lo revelan algunos textos representativos.

\author{
Palabras Clave: \\ viaje y espacio nacional; \\ viaje e imagen del hombre; \\ historia de la literatura mexicana; \\ Manuel Carpio; \\ Ignacio Manuel Altamirano; \\ México y sus alrededores.
}

KEYWORDS:

Travel and national space;

Travel and image of man;

History of Mexican literature;

Manuel Carpio;

Ignacio Manuel Altamirano;

México y sus alrededores.
ABSTRACT: Various manifestations of nineteenth-century Mexican literature articulated a series of ethical and aesthetic resolutions, which contributed to the definition and consolidation of a collective imagery around man and nature. It was sought, thus, to give meaning and cultural transcendence to the project of nation that then arose.

As it is proposed in this work, the literary motive of travel and its perspective were the triggers from which that cultural imagery was configured, on which the concept and the image of the Mexican was concreted and acquired meaning, as some representative texts reveal. 
En 1882, a sesenta y un años de consumada la independencia del país y a quince de definirse e implementarse el proyecto de literatura nacional que fue el programa cultural y literario dominante e integrador de la República restaurada (1867-1876) —trascendente, también, por rebasar los límites temporales e ideológicos del modelo político juarista que le dio origen-, Ignacio Manuel Altamirano manifestaba su extrañeza ante el poco cultivo que había tanto de viajes como de la literatura de viajes en México, más todavía siendo una tradición cultural y literaria, como mestiza, hija "de dos razas esencialmente móviles y atrevidas, muy dadas a los viajes y apasionadas de las aventuras, como fueron la raza española del siglo Xvı y la raza azteca [de las centurias anteriores]" (1988: 216).

$Y$ es que los viajes y sobre todo la literatura que motivaban, eran considerados por Altamirano enunciados éticos y estéticos imprescindibles, fundamentales para la conformación de una cultura y una identidad propias, nacionales, ya que posibilitaban el reconocimiento de la fisonomía física y moral, de las costumbres y los valores que determinaban las relaciones del individuo consigo mismo y con el entorno humano y cultural, así como también con el proceso histórico nacional, todo lo cual permitiría a los miembros de la colectividad visualizarse e integrarse como parte de un todo y así enfocarse en la consecución de proyectos y acciones comunes. Haciéndose eco de las ansias y del espíritu viajero de sus contemporáneos románticos (que veían en el viaje y en la reflexión y los enunciados que motivaba una vía de acceso a una conciencia histórica y cultural de individuos y colectividades, lo cual posibilitaba su integración al proyecto universal divino), se asumía que estos reconocimientos resultado del peregrinar del hombre estimularían o refrendarían la conformación de una conciencia representativa y trascendente, a partir de la cual se daría sentido y orientación a los diversos proyectos colectivos que daban sustento a la nación en el marco de la República restaurada.

En una amplia reflexión a manera de introducción con la que presentaba el Viaje a Oriente (1882), de Luis Malanco, Altamirano consideraba que

después de Humboldt hay mil [extranjeros] viajeros y aun viajeras que han escrito libros sobre México, unos apasionados o burlones como los de Lowestern y el de madame Calderón [de la Barca], otros justos como los de Stephan 
Bullock, los de Wards, de Ernesto de Vigneaux o Charnay, pero todos igualmente interesantes.

Sólo los mexicanos hemos escrito poco [acerca de México,] acerca de nuestro país. Figúrasenos que hablar de nuestras poblaciones, de nuestras montañas, de nuestros ríos, de nuestros desiertos, de nuestros mares, de nuestras costumbres y de nuestro carácter es asunto baladí, y que al ver escrito en una página de viaje un nombre indio, todo el mundo aquí ha de hacer un gesto de desdén.

Quizás tengan razón los que tal temen. Todavía en México, aunque menos hoy que antes, causa más agrado la descripción de un país extranjero, que el de una localidad mexicana, y por eso no es raro, sino muy frecuente, encontrar lectores que saben dónde están los Alpes y cómo son, [pero] que no saben dónde está el Nayarit [ni] qué cosa es; que conocen la descripción de las ruinas de Pompeya [pero] que no tienen ni idea de las ruinas de Uxmal o de Mitla.

Hay cierta repugnancia para conocer el país nativo y esta es la causa de que no pueden desarrollarse vigorosamente todas las ramas de nuestra [cultura y] literatura nacional. Sólo el tiempo y la civilización harán desaparecer estos que son hábitos de la vida colonial.

Por eso nuestra literatura de viajes, en el interior del país, es singularmente escasa. No tenemos una sola colección pintoresca o descriptiva; artículos sueltos, narraciones aisladas, algún pequeño estudio publicado hace años en [periódicos como] el Museo, el Liceo, el Álbum [Mexicano]; algunas estampas litográficas: eso es todo.

[...] Por lo demás, silencio en toda línea. El país se conoce por los pequeños catecismos de geografía elemental de las escuelas primarias que ni son todos buenos, ni completos (1988: 229-230).

Las reflexiones de Altamirano, sensibles y sesudas como siempre, han signado, sin duda, la comprensión y explicación, sobre todo la valoración de esta supuesta ausencia del motivo, forma y perspectiva de la literatura de viajes en la tradición literaria y cultural mexicana. Así, se ha convertido en un lugar común, en un tópico acríticamente asumido por la historia y crítica literaria y cultural, la consideración de que hay una carencia de esa literatura dentro de nuestra práctica artística, situación que se deplora dado que tanto la acción de viajar como el tipo de literatura a que da origen se asumen temática y composicionalmente como dominantes y definidoras, como el detonador de la modernidad decimonona al propiciar el conocimiento dinámico y dialéctico, crítico del mundo, a través de interacciones con otras realidades humanas, culturales e históricas diversas, mismas que conducen a los narradores y poetas — gracias al pacto de ficción, también 
a los lectores-, al redescubrimiento y reconfiguración de su propia imagen tanto como la del espacio-tiempo en el que se desenvuelven.

En el contexto académico e histórico cultural actual, sin embargo, considero que habría que atenuar la contundencia de las reflexiones de Altamirano, máxime atendiendo el estado del arte y las recuperaciones textuales de estudiosos como Felipe Teixidor en Viajeros mexicanos (siglos XIx y XX) (2002 [1939]) y Vicente Quirarte en Republicanos en otro imperio. Viajeros mexicanos a Nueva York (1830-1895) (2009), el primero de los cuales refiere y documenta al final de su compilación alrededor de setenta libros de viaje sólo durante el siglo XIX, lo que desdice o matiza al menos la inexistencia o parquedad de su cultivo dentro de la tradición cultural y literaria nacional. Asimismo, habría que señalar que la reciente teoría de los géneros ha problematizado y establecido una diferencia entre el "relato de viaje" y la "literatura de viaje" a la que refiere el guerrerense; el primer concepto alude a "cierto itinerario presuntamente recorrido [que] se erige por sí mismo en incuestionable sujeto principal" y en el que "no se puede separar de ningún modo lo documental [o testimonial incluso] de los recursos atribuidos a la 'literariedad'" (Carrizo: 10, 11), mientras que el segundo alude a aquel discurso ficcional casi siempre identificado con las realizaciones narrativas, en el que "cualquier referencia al itinerario se subordina a vicisitudes de la existencia de los personajes" (10). Pese a las posibilidades genéricas que, sin duda, ofrecen estas diferenciaciones conceptuales, no abordaré dicha problematización, pues lo importante en el marco de este trabajo son los propósitos, las intenciones éticas y estéticas referidas a la representación y redescubrimiento de lo mexicano a través de lo que en la época se consideraba como literatura de viajes.

Retomando la directriz y el razonamiento iniciales, si bien reconozco la pertinencia y lo particularmente incisivo y certero de algunos de los señalamientos de Altamirano al anticipar en mucho varios de los postulados en los que se fundamentaría la filosofía de lo mexicano poco más de medio siglo después, esto es entre 1934 y 1952 aproximadamente, ${ }^{1}$ considero también que lo dicho por el escritor guerrerense centra — reduce — toda

1 Como el sentimiento de inferioridad y la consiguiente autodenigración señalados por Samuel Ramos en El perfil del hombre y la cultura en México (1934) y asumidos incluso por Octavio Paz en El laberinto de la soledad (1950). 
su discusión en torno a la vigencia e incidencia de un género literario, el de la literatura de viajes, lo que lo conduce a obviar y minimizar —a él, que tan sensible era a las particularidades y posibilidades artísticas - el hecho de que el viaje es también un tema que adquiere una función semántica vertebradora, convirtiéndola por eso en una dominante, en un motivo y perspectiva literarios que articularon, que dieron cohesión, tanto a la tradición de la novela mexicana moderna (iniciada en 1816 con la publicación de El periquillo sarniento, de José Joaquín Fernández de Lizardi), como también a la tradición poética nacional (que comienzan a definir, no necesariamente los poetas patrióticos, ${ }^{2}$ sino los lateranenses neoclásicorománticos al articular conscientemente un perfil no sólo temático, sino valorativo, composicional y estilístico propio a partir de 1836). ${ }^{3} \mathrm{Y}$ es que el viaje desempeñó un papel y función decisivos dentro de la tradición literaria y cultural mexicana que se gestaba, al incidir directamente en la composición, en la realización y significación concretas de los elementos básicos del relato en el caso de los textos narrativos — sobre todo en la perspectiva de narradores y personajes, esto es en el punto de vista que asumían para describir y valorar al mundo-, así como en la elaboración de los elementos líricos y en la utilización de los recursos retóricos en el caso de la poesía; tal motivo y tal perspectiva determinaron también la resolución estilística de los textos, al condicionar la selección y el entramado, la integración/adecuación específica de las formas o modelos ofrecidos por la tradición y mediante los que se configura composicionalmente un significado, una imagen ética y estética del hombre y del mundo, todo lo que redunda en el diálogo dinámico y dialéctico, por eso mismo original, de los textos artísticos concretos y en la conformación de la tradición literaria en general (cfr. Bajtín 1988).

Precisamente en este contexto de reflexión, considero que la poesía descriptiva de Manuel Carpio escrita entre 1832 y 1849, la colección de

2 Si bien estos poetas mantienen viva una tradición poética a través del verso y el uso de distintos recursos retóricos, sus planteamientos textuales no alcanzan una autonomía ética y estética aunque sea relativa, al no trascender las significaciones del momento ni articular una síntesis trascendente del hombre y del mundo.

3 Recuérdese que en 1836 se fundó la Academia de Letrán, la asociación que definió un proyecto temático y de difusión literaria a partir del cual se buscó alcanzar la emancipación literaria y cultural de México (Martínez 1955). 
vistas litográfico/literarias titulada México y sus alrededores (1855), y la novela La Navidad en las montañas (1871), de Ignacio Manuel Altamirano, son manifestaciones representativas de la presencia y posibilidades del viaje como motivo y perspectiva en tres de los géneros literarios más importantes de la tradición literaria mexicana durante su periodo de definición y consolidación (1836-1870), pues se erigen como resoluciones artísticas concretas que, de manera consciente, buscan articular una imagen discursiva e icónica de México y el mexicano, dentro del proyecto de mexicanización de la literatura definido por la Academia de Letrán, primero, y posteriormente, por el programa de literatura nacional que definió e impulsó Ignacio Manuel Altamirano a partir de 1868. Debo señalar que la orientación del trabajo es meramente explorativa, no exhaustiva, pues la extensión del corpus rebasa por mucho el espacio de este trabajo, por lo que tan sólo me referiré a unas cuantas obras representativas de cada una de las manifestaciones genéricas señaladas. En este contexto debo agregar también que muchas de las reflexiones y caracterizaciones hechas aquí son susceptibles de extrapolarse al resto de la tradición literaria hispanoamericana, pues recorren transversalmente la cultura y la literatura del siglo decimonono, permitiendo reconocer el sello indeleble de la centuria, el referido al sino romántico de la cultura y literatura mexicana.

José Emilio Pacheco se hace eco de la historia y crítica literaria al considerar que fue Manuel Carpio (1791-1860) el poeta al que "le corresponde el gran mérito de haber redescubierto para la poesía el paisaje mexicano como tema de celebración" (39), luego de las barrocas descripciones de la Grandeza mexicana (1604) o de la Rusticatio mexicana (1781) que en su momento formularan Bernardo de Balbuena y Rafael de Landívar respectivamente. Y es que con poemas como "México", "El Popocatépetl", "Al río de Cosamaloapan", el vate veracruzano se dio a la tarea de descubrir y representar artísticamente la naturaleza mexicana a partir de un discurso poético de una plasticidad particularmente lograda, ${ }^{4}$ mediante el que se

4 La poesía de Manuel Carpio fue compilada en 1849 por su cercanísimo José Joaquín Pesado. Fue publicada en una segunda edición corregida y aumentada en 1860, la que es la versión más conocida. 
manifiesta una perspectiva exaltada e idealizada sobre la realidad nacional y la cual expresa cabalmente el imaginario del nacionalismo criollo que fundamentó la concepción casi mesiánica de México, del suelo patrio como un edén, como un lugar pródigo y de la abundancia, como un paraíso de los elegidos (Rubial 2010); dicha formulación ideológica, que fue, por lo demás, uno de los factores que justificó e impulsó en mucho las ansias independentistas de los criollos novohispanos (Brading 1998), determina en ese sentido la descripción y valoración de las características del espacio poetizado:

Espléndido es tu cielo, patria mía, de un purísimo azul, como el zafiro:

allá tu ardiente sol hace su giro

y el blanco globo de la luna fría.

\section{$[\ldots]$}

¡Qué soberbios y grandes son tus montes!

¡Cómo se elevan hasta el alto cielo!

¡Cuán fértil, cuán espléndido es tu suelo!

¡Qué magníficos son tus horizontes! (Carpio 1860: 203)

\section{[...]}

De tristes cerros la nubosa cima y en sus abismos la fecunda tierra ricos metales sin medida encierra, que el hombre vil más que el honor estima.

\section{$[\ldots]$}

A México el Criador en sus bondades le ha dado un aire diáfano, sereno, aguas hermosas, fértil terreno, verdes campiñas, ínclitas ciudades. (205)

Como puede advertirse en la espulgada cita, "México", de Manuel Carpio, es un poema que exalta e idealiza la fecundidad prodigiosa de la naturaleza mexicana. Mediante una descripción particularmente ágil y 
dinámica que capta los contrastes de ese espacio-tiempo patrio, se revela al mismo tiempo la total vigencia del espíritu romántico —-mejor dicho, su influencia en el neoclasicismo mexicano- que permite advertir y valorar los matices de la realidad descrita. En este contexto hay que decir que el hablante poético de "México" — poema compuesto por cincuenta y tres cuartetos y que forma parte de la compilación titulada Poesías - ${ }^{5}$ Ilega a configurar un código léxico y referencial propio, que tiene en la adjetivación superlativa, en el tono y ritmo ágil del verso y en la perspectiva exaltada que ayudan a crear el polisíndeton y los signos de admiración constantes, así como en el providencialismo a partir del cual se describe y explica al mundo, los elementos con los que se representa poéticamente a la naturaleza mexicana de una manera novedosa y original, que trasciende las imágenes y la relación hombre/natura planteadas por los anteriores modelos éticos y estéticos de la tradición.

Sin embargo, quiero llamar la atención sobre el motivo y la perspectiva a partir de la cual se plantea la resolución artística del poema. Y es que el yo lírico configura su discurso poético como un vuelo imaginario, como un viaje poético que le permite conocer y describir los diversos y contrastantes paisajes y seres que lo habitan, gracias al cual tiene la posibilidad de visualizar y concientizar las particularidades que conforman al espacio-tiempo patrio:

Pero cansada de volar mi mente [por los distintos espacios mexicanos], cedo al peso de tanta maravilla, y aquí en el polvo sin vigor se humilla, y se anonada de vigor mi frente. (Carpio 1860: 209; los subrayados son míos)

Revelador es el hecho de que el acto poético sea planteado y asumido como un vuelo, como un viaje, pues gracias a ello el hablante caracteriza, enumera y puede realizar la síntesis poética de las particularidades del espacio-tiempo nacional desde una perspectiva asombrada, lúdica y emocionada, que lo lleva a articular diversas y dinámicas panorámicas sobre

5 El poemario fue publicado originalmente en 1849 en la Imprenta de M. Munguía por el gran amigo de Manuel Carpio, el poeta neoclásico-romántico José Joaquín Pesado. 
la topografía, la flora y fauna patrias, configurando así sendas imágenes poéticas que tienen en la acumulación y la enumeración los recursos estéticos a partir de los cuales se conforma y se le da sentido a esa realidad magnífica y avasallante que se impone. Por otro lado, es pertinente señalar que, pese al apego a la norma clásica de Manuel Carpio como poeta, el principal mérito del motivo del viaje es que le permite al hablante poético re-descubrir, sobre todo re-nombrar ese espacio-tiempo mexicano con códigos y voces de la propia tierra, de las propias culturas y lenguas autóctonas, lo que hace a la poesía, como una de las expresiones discursivas de las bellas letras, participar en la definición y construcción tanto icónica como discursiva del entorno nacional y de un orgullo y una conciencia patrias:

¡Qué grato es ver los altos cocoteros ceder al peso de sus frutos ricos, y flotar sus flexibles abanicos, al soplo de los céfiros ligeros! $[\ldots]$

Allá en Oajaca embelesado admiro en la campiña fértil y lozana, verdes nopales de esplendente grana hermosa cual la púrpura de Tiro.

En las selvas revuelan los zorzales, merlas, tucanes de plumajes gayos, encarnados y verdes papagayos, tordos azules, rojos cardenales, colibrís mil de bullicioso vuelo de azules plumas, verdes y doradas, del viajero arrebatan las miradas, como el arco magnífico del cielo.

En México plasmó naturaleza bosques inmensos de árboles salvajes bajo cuyos densísimos follajes se propaga intrincada la maleza.

(Carpio 1860: 205, 206; el subrayado es mío) 
Otro tanto pudiera decirse del poema titulado "El Popocatépetl", el cual poetiza el ascenso al emblemático volcán mexicano, como una posibilidad que le permite al alma "gozar sublimidad tan varia" (218); la perspectiva asombrada e hiperbólica desde la que se reconocen y enuncian las características naturales a las que se enfrenta el yo poético, refuerza la sensación de re-descubrimiento de una realidad ignota e imponente donde en medio de "la soledad más espantosa / intrépido el viajero[, o sea el hablante poético] se adelanta" (219). Sin embargo, y quizás esto es lo más importante, el viaje poético a la cima del coloso le permite a la voz lírica dar cuenta de una realidad hasta entonces sólo referida mas no conocida, a la vez que realizar la síntesis poética no nada más de la montaña, sino del entorno que se definía y conocía, México:
[...] y hoy desde su alta y prodigiosa cumbre. Ven los ojos pasmados y perplejos, dentro de los lejanos horizontes, grandes llanuras, azulados montes, lagos, caminos, pueblos a lo lejos. Detrás de los celajes de Occidente, teñidos de oro y púrpura lumbrosa, cual gigante se ve precipitarse del sol inmenso el disco reluciente más allá de los cerros y gloriosa levantarse la luna en el oriente. (Carpio 1860: 220-221; el subrayado es mío)

Considero de particular importancia y trascendencia ética y estética que el motivo y la perspectiva del viaje en la poesía de Manuel Carpio no se reduce sólo a configurar una plástica y edulcorada imagen del espaciotiempo mexicano, sino que, dialécticamente, permite reconocer también las contradicciones históricas y culturales que condicionan al espaciotiempo mexicano objeto de la representación artística, pues como enuncia el hablante poético al final de "México",

Es mi voto postrero, patria mía, pedirle al cielo que dichosa seas [...]

A tu seno retorne la alegría, se unan tus hijos con amante lazo, 
suelte las armas tu cansado brazo, como en un tiempo cuando Dios quería.

De la prosperidad, en fin, la copa benigno el cielo sobre ti derrame mientras el mar enfurecido brame entre tus playas y la altiva Europa. (Carpio 1860: 210, 211; el subrayado es mío) ${ }^{6}$

Si bien la historia y la crítica literaria siempre han tachado a Carpio de ser un poeta evasivo y escapista, que rehúye el compromiso histórico con el momento que le ha tocado vivir, considero que queda de manifiesto que dicha ambigüedad es sólo aparente, pues las estrofas finales de "México" tienen la capacidad de señalar los limitantes de su momento histórico, al mismo tiempo que ubicar la superación de esos límites y contradicciones en el presente en devenir histórico y cultural que condiciona al propio texto.

Antes de cerrar esta reflexión sobre el motivo y perspectiva del viaje en la poesía del vate veracruzano, he de señalar que Pablo Mora se da a la tarea de estudiar en lo específico la poesía religiosa del bardo y reconoce en ella influencias concretas de poetas franceses e italianos tanto en la perspectiva y visión del mundo a partir de las cuales se le da sentido a la realidad, como también en las resoluciones formales desde las que se configura esa imagen particular del mundo. Dice Mora que

la poesía de Carpio era, en gran medida, sacada de escritores como Chateaubriand, Lamartine y Manzoni, modelos todos ellos que representaban una escritura que hizo de la literatura sagrada, de viajes y de la historia, una poética de reconstrucción en tanto significaba una respuesta y una estabilidad espiritual frente al desamparo que había significado el siglo xVIII, el escepticismo y la poesía profana (2000: 65; el subrayado es mío).

\section{Y añade que}

Carpio, sin precedentes en la literatura mexicana, iniciaba [con su obra] una actividad literaria en donde al mismo tiempo que hace de la poesía una glosa del

6 El poema fue escrito en 1838, en el marco de la Guerra de los Pasteles entre México y Francia, lo que ayuda a entender el hecho de que Carpio, un ferviente conservador, exprese al más puro estilo liberal la separación entre México/América y Europa. 
relato de viajes, se apropiaba de un material en el que el poeta buscaba pintar poéticamente los escenarios [naturales y religiosos] descritos por los escritores del cristianismo. Sin duda, esta actividad se desprendía de aquello que era la verdadera función de la literatura: tenía que enseñar, ser útil, moral y deleitar (70-71; el subrayado es mío).

Si bien buscan explicar el horizonte y las resoluciones específicas de la poesía religiosa del vate veracruzano, me parece que estas consideraciones son válidas y extrapolables a textos entendidos por su autor como poesías descriptivas y a las que pertenecen poemas como "México", "El Popocatépetl" y "Al río de Cosamaloapan", entre otros, pues en ellos, a la vez que puede advertirse la percepción romántica de la naturaleza como un proyecto divino, se reconoce también el papel particularmente importante que desempeñaron el viaje y su perspectiva en la descripción del mundo como una entidad propia, nacional, patria.

Luego del azaroso proceso de apropiación y dominio tanto por parte del academicismo oficial como de las empresas comerciales que documenta Arturo Aguilar Ochoa (2007), la práctica litográfica alcanzó su carta de naturalización en el panorama cultural del país entre los años de 1840 y 1855 con los diversos proyectos editoriales que impulsaron la Academia de Letrán y sus seguidores como estrategias enfocadas a divulgar el proyecto de mexicanización de la literatura y la cultura para alcanzar su emancipación de toda otra tradición.

Tras superar la práctica y presencia un tanto incidental y a la manera de retratos que ilustraban la semblanza biográfica de algún personaje ilustre de la historia y la cultura patria, hispana o europea - como las efigies de Lope de Vega, Bartolomé Esteban Murillo, José Joaquín Fernández de Lizardi, Bretón de los Herreros, Lord Byron o Lamartine, que aparecieron publicadas en El Recreo de las Familias (1838) o, muy esporádicamente, la escena de alguna narración de folletín —como es el caso de la serie de investigación Bicetre, la historia del manicomio francés, en la citada publicación-, la litografía cobró auge a partir de 1843, cuando, de manera constante, comenzaron a aparecer en las revistas y los periódicos culturales y literarios de México, sobre todo en las páginas del Museo Mexicano o Miscelánea Pintoresca de Amenidades Curiosas e Instructi- 
vas (1843-1846), elaboradas estampas que, funcionando como paratextos - es decir, como reforzadores de los tópicos del enunciado literario principal-, ayudaban a exponer los temas o planteamientos de alguno de los artículos de las secciones de botánica, historia, geografía o cultura: la lámina titulada el "Árbol de las manitas" (1843) inauguró esta nueva etapa de la litografía en México:

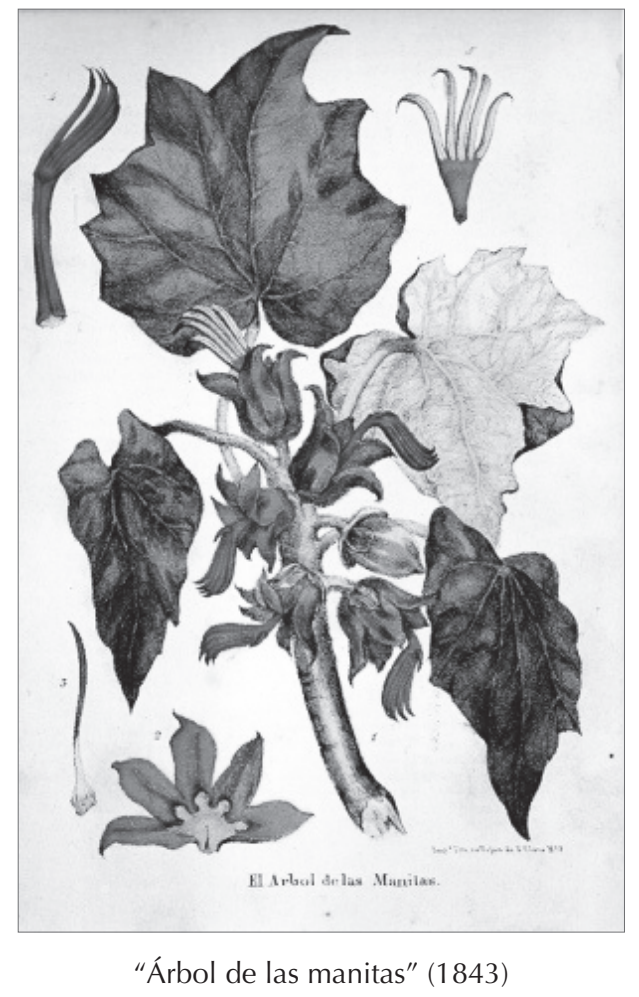

Desarrollando la práctica del Museo Mexicano, otros periódicos de la década de 1840-1850 continuaron incorporando ilustraciones litográficas como apoyos paratextuales a los artículos que versaban sobre la naturaleza, la cultura, la historia y la geografía nacionales, lo que así revelan publicaciones como la Revista Científica y Literaria de México (1845-1846), el Álbum Mexicano (1849) o la Ilustración Mexicana (1851-1855), entre varias otras. Sin embargo, hay que reconocer también que poco a poco esos 
trabajos litográficos dejan de ser entendidos como meros apoyos plásticos a los artículos literarios y ambos textos comienzan a concebirse como un todo, como un binomio conformado por la suma integrada del texto plástico y el texto literario; historiadores del arte y de la litografía como Manuel Toussaint (1934) y María Esther Pérez Salas (2005) han señalado el hecho de que el artista plástico y el artista literario, de laborar de manera independiente e inconexa, comenzaron a crear de manera conjunta esos artículos y cuadros, trabajando juntos la idea que cristalizaría en la realización de la imagen plástica y escrituraria. Esta unidad textual puede advertirse, sobre todo, en los binomios publicados en la sección de geografía del Álbum Mexicano (1849), donde las imágenes litográficas atienden puntualmente las características y el enfoque planteados por las imágenes literarias, tal como se puede observar en el texto que describe Teotihuacán en el Estado de México, por mencionar sólo un ejemplo:

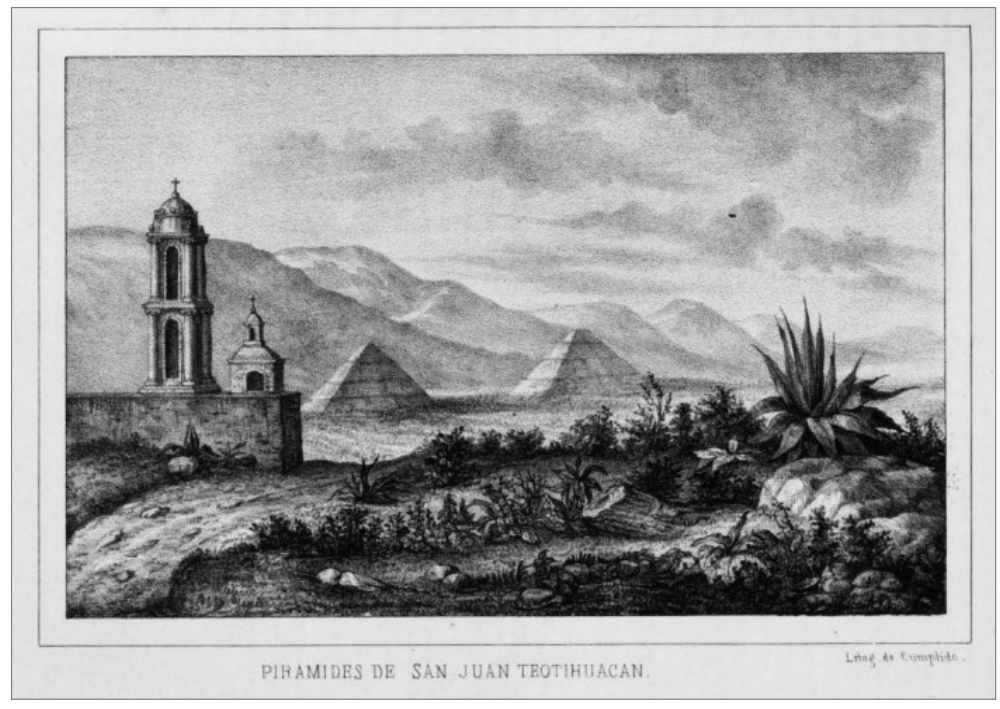

"Pirámides de San Juan Teotihuacán"

Sin dejar de señalar la vertiente conformada por los artículos y cuadros costumbristas en los que la atención estaba centrada en el reconocimiento y caracterización de los tipos y escenas culturales que conviven y conforman así a la realidad mexicana, reconociendo y otorgando de esta manera 
una fisonomía propia al hombre y la cultura nacional —reconocimiento que coadyuvó, sin duda, en la conformación de un discurso y un imaginario nacionalista propios-, quiero destacar en este marco el papel tan importante y particular que tuvo esa otra variante de la tradición de los artículos y cuadros costumbristas y que fue la de las vistas de paisajes y escenas. Y es que, apropiándose e incorporando al binomio plástico/literario la configuración de tipos y escenas, la práctica de las vistas se dio a la tarea de re-presentar y re-descubrir plásticamente la realidad citadina y natural mexicana, dotándola literariamente, además, de una significación histórica y cultural que la hace representativa y trascendente, como sucedió, entre otros, con los textos que mencioné antes, los cuadros plásticoliterarios de Teotihuacán, o también los de Uxmal, Campeche o Cozumel.

Es en este entorno que destaca como una de las cumbres de esta práctica litográfica/literaria ${ }^{7}$ el compendio titulado México y sus alrededores. Colección de vistas monumentales, paisajes y trajes del país, obra publicada en 1855 bajo la dirección del impresor francés mexicanizado Joseph Decaen, con dibujos litográficos de Casimiro Castro, José Campillo y Guadalupe Rodríguez y con artículos descriptivos literarios de Marcos Arróniz, José María Roa Bárcena, Florencio María del Castillo, José Tomás de Cuéllar, Francisco González Bocanegra, José María González, Hilarión Frías y Soto, Luis Gonzaga Ortiz, Manuel Payno, Anselmo de la Portilla, Vicente Segura Argüelles, Francisco Zarco y Niceto de Zamacois. La colección reúne cuarenta y seis cuadros plásticos y literarios, clasificados en treinta y siete vistas, siete representaciones de trajes y tipos, dos de escenas costumbristas y una museográfica, además de un plano general de la Ciudad de México.

Como se ha expuesto con largueza en otro espacio (Bobadilla: 111150), la naturaleza física y arquitectónica mexicana es descrita al mejor estilo romántico, esto es, como proyecto que debe su riqueza y armonía gracias a la benignidad y generosidad del Todopoderoso, razón por la cual México y sus alrededores se da a la tarea de describir las "sublimes catedrales y magníficos palacios; [los] galanos acueductos y hospitales; [los] colegios y prisiones; [las] plazas y fuentes" (Zarco: 5) que pueblan y enri-

\footnotetext{
7 Junto con Los mexicanos pintados por sí mismos, editados en libro el mismo año.
} 
quecen a la Ciudad de México. Y, lo importante, el artificio ético y estético que sólo la hermandad de la literatura y la pintura pudieron resolver: se realiza esa serie de descripciones que representan y explican la calidad artística y la grandiosidad y magnificencia de las edificaciones, fuentes y plazas, sólo que esas obras monumentales que son la catedral metropolitana, la plaza de la constitución, el Palacio Nacional o el de Minería, las casonas de Tacubaya, se visualizan siempre en medio del exuberante y pródigo marco que supone el entorno americano, integradas franca y espontáneamente a la naturaleza mexicana.

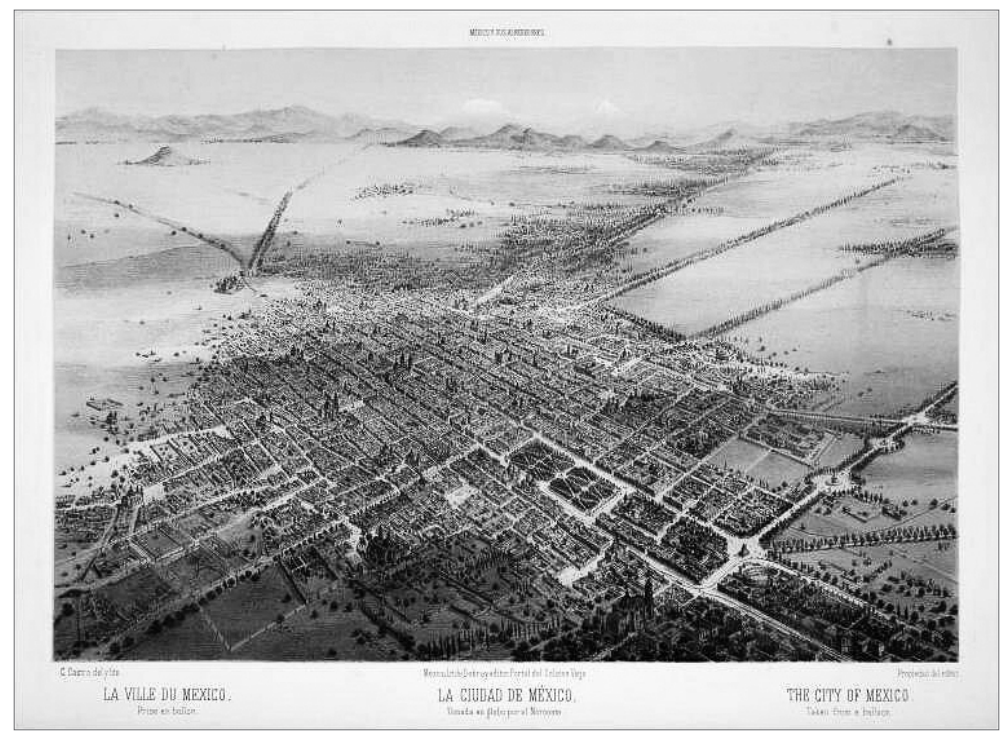

"La Ciudad de México", en México y sus alrededores (1855)

Es en este contexto, precisamente, que el motivo, la forma y la perspectiva del viaje despliega nuevamente sus posibilidades significativas. $Y$ es que tomando como enclave focalizador el globo aerostático que permite a los narradores desplazarse natural y francamente a lo largo y ancho de la geografía de la Ciudad de México y de las diversas zonas aledañas —atalaya aérea que, por lo demás, causaba furor en la sociedad mexicana de la época y que está representada icónicamente en varias de las vistas que conforman al volumen, subrayando así su importancia perceptual一, México y sus alrededores. Colección de vistas monumentales, paisajes y 


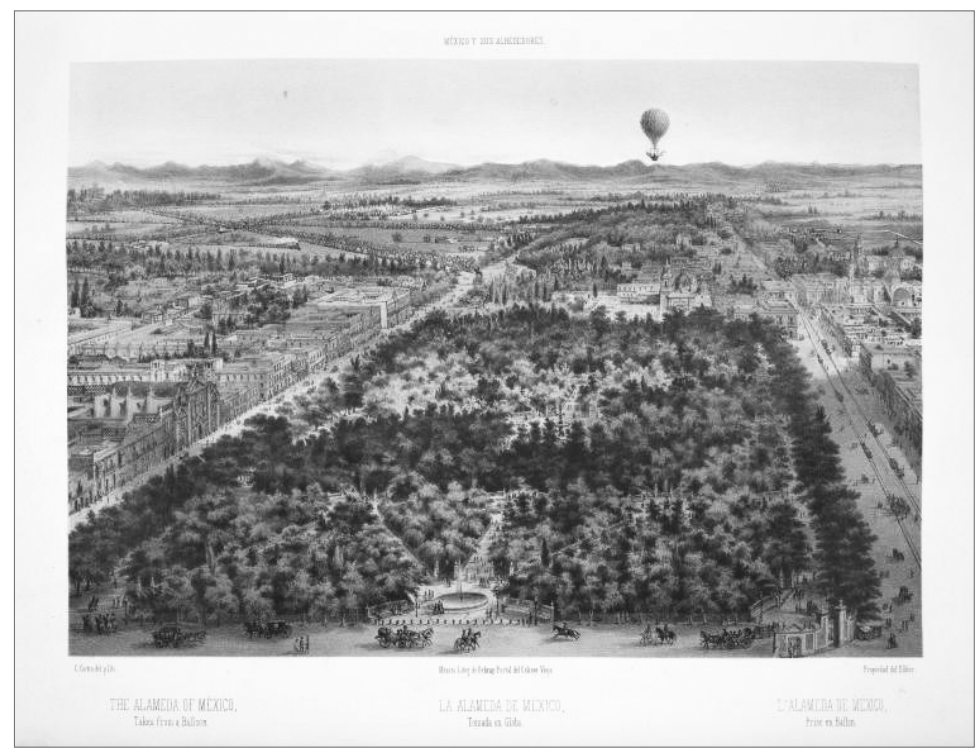

"La alameda de México", en México y sus alrededores (1855)

trajes del país da cuenta, recupera, re-valora y re-descubre, otorga una representatividad cultural a la riqueza sobria de la capital del país, gracias al desplazamiento y enfrentamiento empático y sorprendido de los narradores, que realizan la descripción puntual de las dimensiones y estilos de los principales edificios de la no casualmente Ilamada por Charles Joseph Latrobe como la "Ciudad de los palacios" (1836), según apunta Héctor de Mauleón (2015). Sin embargo, lo importante es que ese viaje por México y sus alrededores no se realiza nada más desde la perspectiva arquitectónica: más importante quizás, la obra define y otorga una dimensión y sentido histórico y ético a las soberbias edificaciones y paisajes que describe, insertándolos dialécticamente tanto dentro del devenir de la colectividad como también dentro del proyecto de orden y sentido divino de ascendencia romántica. Así, gracias al viaje que encuentra una lucida resolución artística en la perspectiva aérea/panorámica del enunciado con doble textualidad — plástica y literaria—, cada uno de los monumentos descritos (palacios, iglesias, plazas, fuentes y paseos: a cual más sorprendentes) se muestra como revelador ya de un momento de la historia de México al asociarse con algún hecho histórico y cultural, ya de un rasgo 
caracterizador de la idiosincrasia y temperamento de México al expresar algunos de sus hábitos y costumbres.

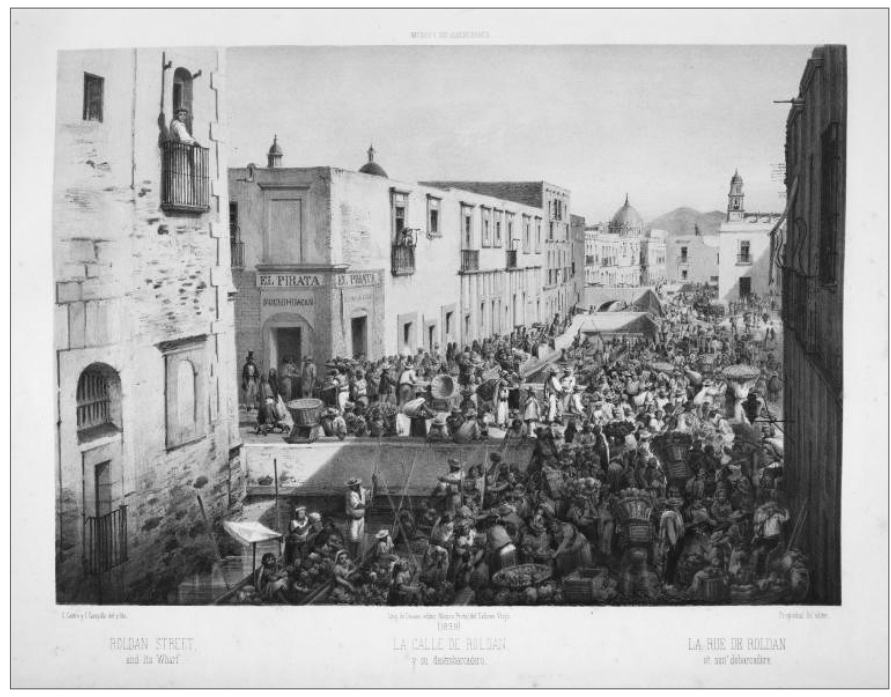

“La calle Roldán", en México y sus alrededores (1855)

No puedo concluir este apartado sin antes señalar al menos dos aspectos. El primero de ellos está referido al papel protagónico otorgado a la naturaleza dentro de las vistas —al cielo diáfano e inmenso, a las alamedas y bosques umbríos y espesos-, tal como revela la composición rigurosa de la litografía en dos planos —o escalonada o en diagonal—, uno destinado a dar cuenta de la obra arquitectónica realizada por el hombre, otro, siempre el nivel superior, dispuesto para la natura y cielo exuberantes o las serranías que enmarcan y dan un significado trascendente, espiritual y divino a la obra del hombre. Seguramente en esta disposición plástica está la resolución artística a la certeza referida al hecho de que

lo que hay aquí [en México] que describir vale más que las [solas] masas de piedra. Ahí está el Popocatépetl coronado de nieve; allí las serranías erizadas y salvajes; allí los jardines que halagan a un tiempo la primavera y el otoño en la Tierra-caliente; en otra región Ilanuras inmensas, costas fértiles bañadas por el mar que apenas las acaricia con amor; bosques vírgenes, sabinos y ahuehuetes que nacieron el día de la creación... Aquí se estudia la obra de Dios, que es más grande que la de los hombres (Zarco 1855: 4-5; el subrayado es mío). 


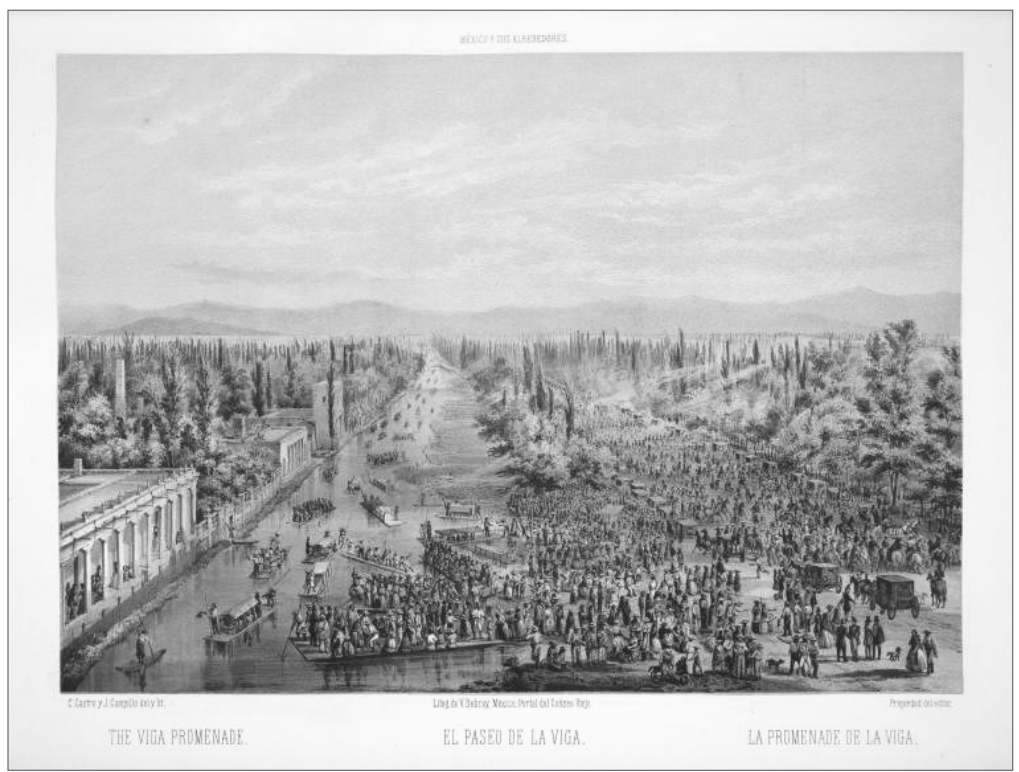

"El Paseo de la Viga", en México y sus alrededores (1855)

Se logra de esta manera, la síntesis dialéctica entre historia/cultura y naturaleza, pues así la colección articula una imagen icónica y discursiva que ayuda a definir, a dar representatividad y trascendencia a un espaciotiempo cultural mexicano, a partir de establecer una contigüidad histórica fundacional entre el proyecto divino que es la naturaleza mexicana y los monumentos y edificaciones que lo pueblan.

El otro aspecto a mencionar refiere al hecho de que el viaje, que encuentra su resolución artística en la articulación de sendas imágenes plásticas y literarias que, como conjunto, se integran y crean una representación más amplia y total del espacio-tiempo mexicano, no reduce sus posibilidades sólo a la descripción de los monumentos y su entorno físico y natural, sino que, como apunté antes, tiene además la capacidad, sobre todo la sensibilidad ética y estética de representar la vida de la colectividad en su fluir dinámico y contrastante. Y es que las vistas muestran también a los seres humanos que, con sus contradicciones y tensiones, le dan sentido y unidad a esa realidad. 


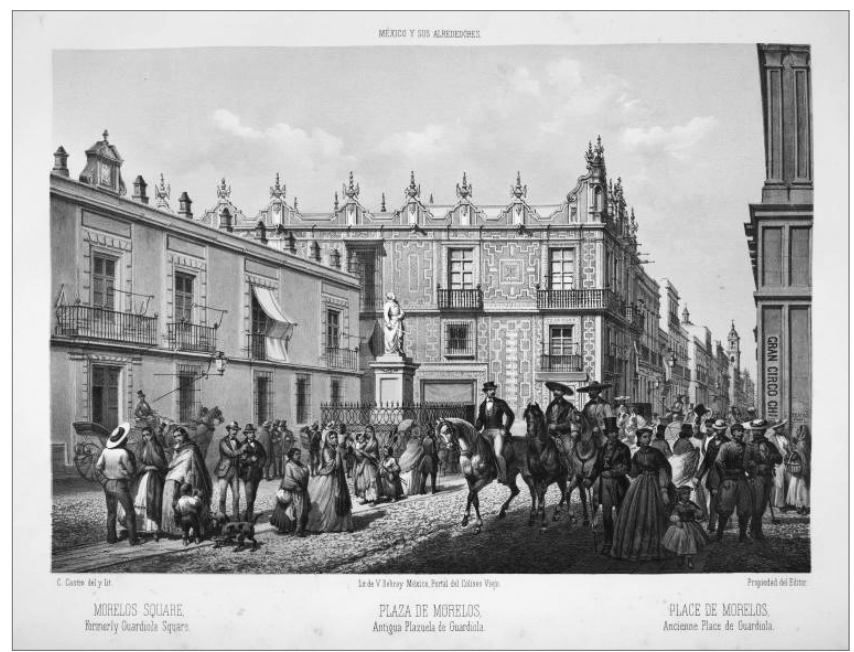

"Plaza de Morelos", en México y sus alrededores (1855)

Establecido esto, quiero comentar rápidamente dos de las litografías de México y sus alrededores, la primera de ellas la titulada "La fuente de la Tlaxpana", que describe parte del antiguo acueducto de Santa Fe, el que fue demolido en 1899 en aras del crecimiento y progreso citadino.

Retomando lo expuesto en otro espacio (Bobadilla: 111-150), podría comentar la belleza churrigueresca de la fuente o la composición en diagonal de la pintura o la uniformidad de la paleta ocre del litógrafo. Sin embargo, prefiero dirigir mis comentarios al hecho de que la fuente es un mero pretexto para plantear tanto visual como literariamente la riqueza y diversidad cultural de México y el mexicano: y es que rebasando la intención de captar la monumentalidad barroca de la fuente - cuya composición arquitectónica, se dice, era semejante a la de la romana Fuente de Trevi-, la vista literaria y plástica es capaz de expresar la diversidad de vivencias humanas y culturales que se dan en México, como lo expresa la pareja burguesa que monta a caballo, que admira la fuente (...de lejecitos, quizá para no mezclarse o ensuciarse con los peones que dan de beber a sus recuas) y que es indiferente e insensible a la experiencia cotidiana de la vida y de la muerte, representadas por los indios que llevan sus mercancías a la ciudad, por el trasiego de los carros, por los juegos de los niños o por los oficios fúnebres que se celebran a las puertas del camposanto del fondo. 


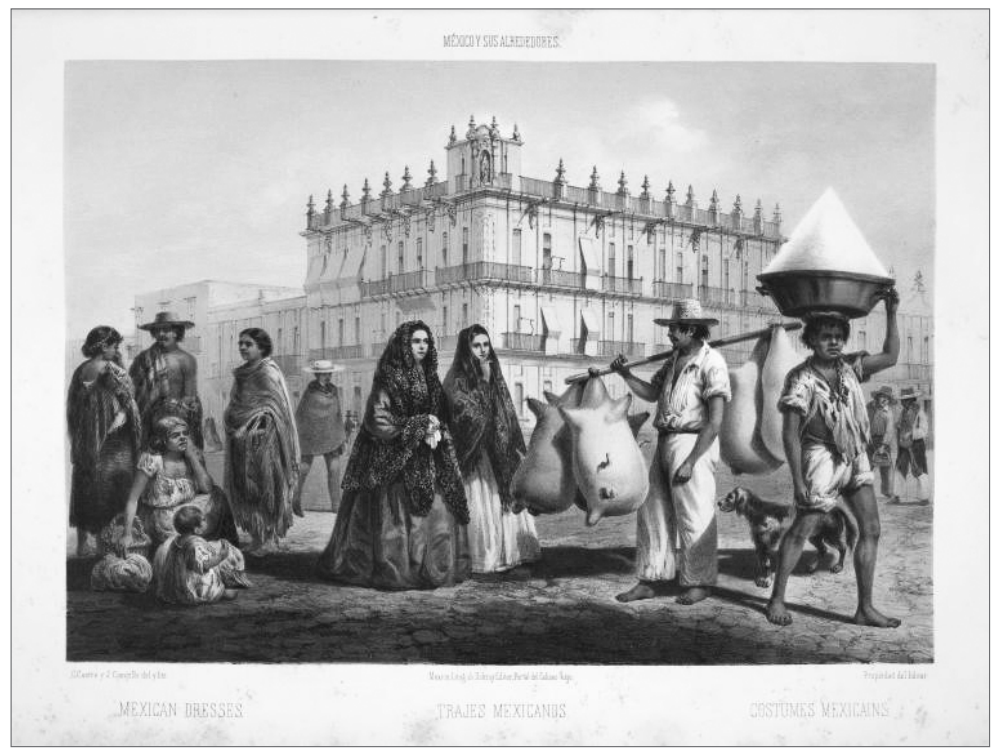

"Trajes mexicanos", en México y sus alrededores (1855)

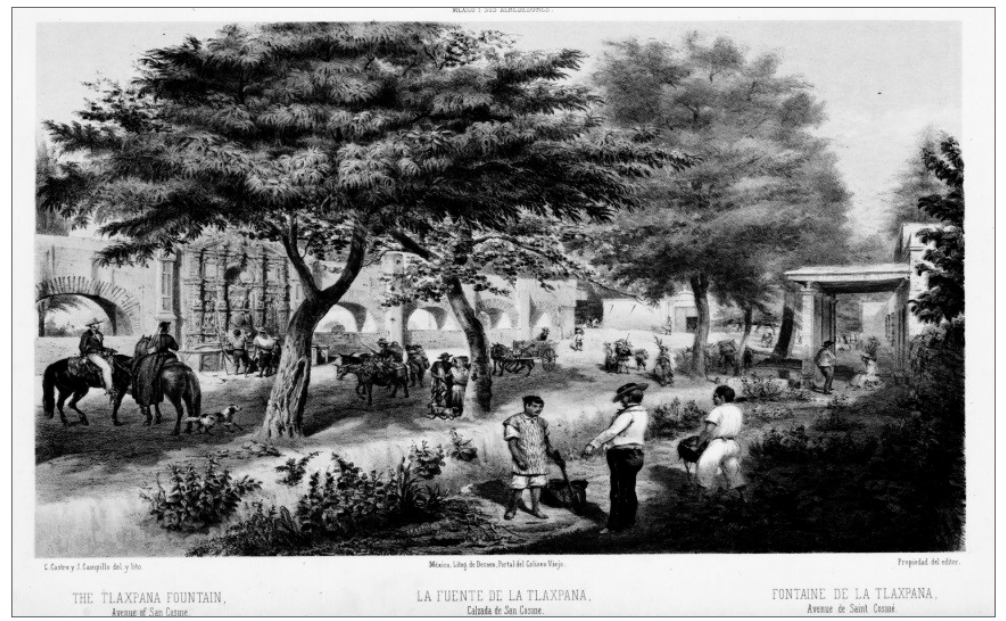

"La fuente de Tlaxpana", en México y sus alrededores (1855)

Otro tanto quisiera comentar sobre la lámina titulada "[Paseo de] las cadenas en una noche de luna", un clásico de la iconografía plástica y literaria decimonona de México: 


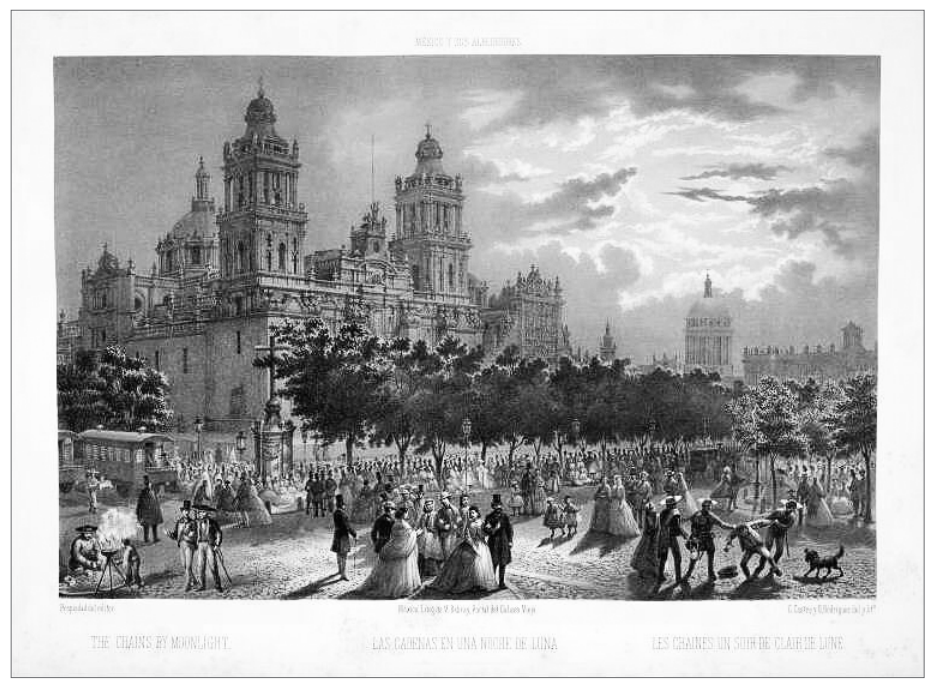

"[Paseo de] las cadenas en una noche de luna", en México y sus alrededores (1855)

La representación literaria y plástica de la cultura de la plaza — de calidad muy superior en su formulación icónica, muy pobre literariamente, fuerza es reconocerlo- permite captar y reconocer la totalidad de la sociedad y la cultura mexicana, que con su mezcla rigurosamente normada de las distintas clases sociales y culturales, está cabal y completamente mostrada por esta litografía; y es que puede advertirse en el centro inferior del retrato a los miembros de la clase alta, mientras que a ambos lados están las vivencias del pueblo, con el vendedor de cacahuates a la izquierda, con el borracho que es detenido por la policía de la Acordada del lado derecho, con la inocente curiosidad medrosa de los chiquillos; en la parte media de la litografía tenemos los paseantes, en dirección a la derecha las mujeres, a la izquierda los hombres. Y sobre esta feria humana, la grandiosidad del horizonte citadino representado por la imponente catedral y el contorno de los otros templos y edificios, que con su perfil nocturno grandioso y melancólico contribuyeron a crear un orgullo y una autosuficiencia para México como espacio-tiempo histórico y cultural representativo y trascendente de un alma específica, la mexicana.

Si bien como motivo, forma y perspectiva está estrechamente ligado al cultivo de la novela como género particular desde la Antigüedad (Bajtín 
1988), sin duda que el viaje marcó y determinó definitivamente el desarrollo de la novela moderna. $Y$ es que tras las andanzas demenciales o aventureras de El ingenioso hidalgo don Quijote de la Mancha (1605), de Miguel de Cervantes, de Robinson Crusoe (1719), de Daniel Defoe, de LoS viajes de Gulliver (1726), de Jonathan Swift o de Cándido o el optimismo (1759), de Voltaire, narradores, personajes y lectores emprenden largos y extenuantes recorridos en los que se enfrentan ya consigo mismo, ya con el Otro, interacciones viajeras que al final los conducen no sólo a reconfigurar su propia imagen y el código de valores a partir del cual le dan sentido al mundo, sino que también, más importante quizás, los conducen a replantear su propia conciencia histórica, esto es, la comprensión y relación del individuo con y frente al flujo del devenir colectivo, diferenciándose así de lo sucedido en la novelística de la Antigüedad, donde los cambios o evoluciones tenían sobre todo un sentido moral.

Quizás las condiciones y posibilidades que el motivo, perspectiva y forma del viaje ofrecían al género novelesco —-movimiento y síntesis, evolución, cambio, transformación- permitieron a Walter Scott la caracterización de ese subgénero novelesco específico que fue el de la novela histórica allá en 1820, con la publicación de Ivanhoe. Y es que sólo a partir del recorrido, los jóvenes protagonistas, pazguatos y apolíticos, podían llegar a definir y asumir una postura, una conciencia histórica que sintetizara y expresara las ansias y los valores trascendentes de la colectividad (Lukács 1957), como lo muestran Los misterios de París (1842-1843), de Eugenio Sué, o Los tres mosqueteros (1844), de Alejandro Dumas, referentes fundamentales del subgénero.

Considero que el paradigma historicista de las tres edades de la poesía y la cultura que planteó Víctor Hugo en el "Prefacio" a Cromwell (1827), ampliamente conocido y asumido como modelo entre los escritores e intelectuales mexicanos tal como lo documentan Blanca Estela Treviño (1996) y Víctor Díaz Arciniega (1996), aunado al hecho desvelado sólo luego de la conclusión de la guerra de independencia de México en 1821 y referido a que había que articular un imaginario y un discurso histórico para sustentar un proyecto político, social y cultural de nación capaz de aglutinar al colectivo, propiciaron el surgimiento y cultivo de la novela histórica como el género literario dominante del periodo comprendido 
entre 1836 y 1870 , hecho reconocido ya en lo individual por los propios escritores mexicanos decimononos como Juan Díaz Covarrubias (1991: 3), ya en las primeras formulaciones historiográficas acerca de la literatura nacional planteadas por Ignacio Manuel Altamirano, quien afirmaba sin ambages que "en México [hasta 1870...] no se ha cultivado sino la novela histórica y muy poco la de sentimiento, la verdadera novela. Para la instrucción popular, es evidentemente más útil la primera" (1988: 235).

$\mathrm{Si}$, como señalé antes, el cultivo de la novela histórica decimonona es amplio y sugerente en cuanto a temas, perspectivas y concepciones de la historia, considero también que La Navidad en las montañas (1871), de Ignacio Manuel Altamirano, tiene el doble mérito de expresar cabalmente la incidencia del motivo del viaje en la conformación de la conciencia histórica nacional, tanto como de exponer el sentido y la función integradora otorgados a la novela durante la época, al conciliar las posturas ideológicas divergentes del periodo y formular un entramado que logra la hibridación de lo bello con lo útil, al entretejer muy lúcidamente el enunciado narrativo a partir de las formas de la novela utópica y de la novela sentimental.

Y es que La Navidad en las montañas, un texto configurado a manera de testimonio, narra el encuentro fortuito de un capitán del ejército liberal durante la guerra de Reforma (1858-1861) con el párroco de una aldea perdida en la sierra, en una fecha especialmente simbólica para el mundo occidental: la Nochebuena como inicio de ciclo de renovación/ salvación humana. Durante una estancia que se extiende por dos días en ese oasis, el militar tiene la oportunidad de conocer la organización social y cultural que el cura ha implementado en el pueblo como resultado de la dimensión no sólo evangélica sino social que le ha dado a su ministerio, misma dimensión que condiciona y determina la vida cultural y moral del pueblo tanto en el ámbito educativo como en cuestiones de salud, higiene y hábitos alimenticios, incluyendo una reformulación de las prácticas del trabajo. Por tales características y significados es que suele entenderse La Navidad en las montañas como una novela utópica, esto es como un enunciado novelesco que describe y explica el funcionamiento de una sociedad ideal, que, en el caso concreto de esta obra, tiene su base en la comunión, en la interrelación de la praxis social y los valores y relaciones 
de un cristianismo primitivo, espiritual, desprovisto de nexos e intereses institucionales, entramado que permite la realización plena e ideal del individuo.

La Navidad en las montañas comienza con una nostálgica y melancólica, oscura y nebulosa descripción anímica del capitán X, el narrador testigo, y del espacio-tiempo que recorre:

El tiempo que pasó [desde mi edad feliz] al darme su poético adiós hacía más amarga mi situación actual.

¿En dónde estaba yo?, ¿qué era entonces?, ¿a dónde iba? Y un suspiro de angustia respondía a cada una de estas preguntas que me hacía, soltando las riendas de mi caballo, que continuaba su camino lentamente.

Me hallaba perdido entonces en medio de aquel océano de montañas solitarias y salvajes. Era yo un proscrito, una víctima de las pasiones políticas, e iba tal vez en pos de la muerte, que los partidarios en la guerra civil tan fácilmente decretan contra sus enemigos.

Ese día [de Nochebuena] cruzaba yo un sendero estrecho y escabroso, flanqueado por enormes abismos y por bosques colosales, cuya sombra interceptaba ya la débil luz crepuscular (Altamirano 2017: 45-46; el subrayado es mío).

Como puede advertirse, la configuración del narrador-personaje como un marginado romántico, tanto a nivel humano como político, así como su deambular casual, incierto y azaroso por los senderos de la vida y de la historia, lo conforman como una entidad atribulada e incomprendida, incapaz de conectarse con el flujo vital e histórico. Es de destacar la representación de la escena a partir de un campo semántico del desasosiego y la tribulación —amargo, angustia, perdido, proscrito, víctima, estrecho, escabroso, sombra-, con tintes grises y oscuros que recuerdan en mucho los planteamientos e imágenes góticas, sobre todo por la técnica del claroscuro, pues de esta manera se concentra la atención narrativa y se refuerza la soledad e incertidumbre del hombre.

Es en este contexto que surgen y se potencian las posibilidades del motivo, forma y perspectiva del viaje. Y es que el narrador testigo, sólo luego de diversas andanzas y experiencias con el Otro, el cura español, y por el espacio-tiempo ajeno de caracterización y significación utópica, la aldea perdida, supera la incertidumbre existencial e ideológica con que inicia la novela y alcanza un estado de conciencia y plenitud individual y colectiva 
que le despeja las dudas primigenias y lo reconcilia como individuo con su esencia humana, política e histórica. Precisamente ante esta indecisión es que el viaje se revela en todas sus posibilidades como la vía para acceder a una síntesis dialéctica: ese recorrido enfrenta al narrador testigo con unas entidades vivas que le permiten no sólo conocer otras posibilidades, otros modelos sociopolíticos, culturales y humanos, sino que lo conducen y obligan a superar aquellos escrúpulos y, más importante, a reconfigurar su código de valores y la imagen del hombre y la historia como entidades vivas y dinámicas. Así, partiendo de grandes aprensiones ideológicas hacia el cura que lo guiará durante sus andanzas por el pueblo y su encuentro con la realidad ajena, ${ }^{8}$ el narrador se enfrenta gracias al viaje a distintas experiencias sociales y humanas que se viven en la apartada aldea y en las que prima la fraternidad y solidaridad colectivas, lo que lo lleva, sí, a reforzar sus críticas ante la sociedad conservadora que políticamente lo persigue, pero, más importante quizás, que lo lleva a re-descubrir los valores y sentido de un modelo y visión del mundo más pleno e integral, el del cristianismo primitivo (por esencial), que no necesariamente estaba reñido con la ideología liberal que profesaba:

Yo comprendo así mi cristiana misión: debo procurar el bien de mis semejantes por todos los medios honrados, a ese fin debo invocar la religión de Jesús como causa, para tener la civilización y la virtud como resultado preciso; el Evangelio no sólo es la buena nueva bajo el sentido de la conciencia religiosa y moral, sino también desde el punto de vista del bienestar social. La bella y santa idea de la fraternidad humana en todas sus aplicaciones, debe encontrar en el misionero evangélico su más entusiasta propagandista; y así es como este apóstol logrará llevar a los altares de un Dios de paz a un pueblo dócil, regenerado por el trabajo y por la virtud, al campo y al taller, a un pueblo inspirado por la idea religiosa que le ha impuesto, como una ley santa, la ley del trabajo y de la hermandad.

8 Puesto que era “¡Español!, me dije yo: eso sí que me alarma; yo no he conocido clérigos españoles más que jesuitas o carlistas, y todos malos. En fin, con no promover disputas políticas, me evitaré cualquier disgusto" (Altamirano 2017: 47), en una expresión del nacionalismo criollo todavía vigente para la época: recuérdese que apenas hacía cinco años que Ignacio Ramírez había escrito y publicado su artículo "La desespañolización", como parte de la sonada polémica que sostenía con Emilio Castelar (cfr. Ruedas: 189-192). 
—Señor cura —volví a decir entusiasmado—, ¡usted es un demócrata[, un liberal] verdadero! (Altamirano 2017: 64).

Es de destacar en este contexto la perspectiva entusiasta y receptiva del capitán, tanto frente a la organización concreta de la vida que había podido implementar el cura en el pueblo, como también ante sus reflexiones y conceptualizaciones, pues esa perspectiva sorprendida y empática del viajero que se enfrenta a realidades no conocidas es precisamente la que le permite realizar la síntesis que le devuelve el sentido a su existencia:

soy lo que el clero llama un hereje, un impío, un sans-culotte, pero yo aquí digo a usted, en presencia de Dios, que respeto las verdaderas virtudes cristianas, como jamás las ha respetado fanático o sayón reaccionario alguno. Así, venero la religión de Jesucristo como usted la practica, es decir como él la enseñó y no como la practican en todas partes [, de una manera dogmática y materialista] (Altamirano 2017: 54).

Ha estado implicado en los señalamientos anteriores, el hecho de que el motivo, la forma y la perspectiva del viaje determinan la resolución artística de La Navidad en las montañas, de Ignacio Manuel Altamirano, al establecer como el elemento composicional dominante el punto de vista exaltado y empático con que el narrador asume los distintos contactos que tiene con la realidad sociocultural y humana que descubre y narra. Con todo, debe señalarse que el entramado estilístico de la obra presenta una complejidad particularmente lograda, pues enriquece la experiencia viajera con la presentación de estampas costumbristas particularmente plásticas - como las escenas navideñas de la misa de gallo o la de la feria popular previa a la celebración o la de los cantos de los villancicos - cuya función y sentido es perfilar el talante moral y colectivo de la aldea; a esto habría que sumar la formulación de la novela sentimental representada en el texto con los amores contrariados de Pablo y Carmen, quienes gracias a los oficios del cura logran superar las barreras sociales y prometen realizar su amor en el presente en devenir del texto.

Antes de cerrar este apartado considero necesario comentar aunque sea rápidamente el final de la obra, que se cierra afirmando que "todo esto [que he narrado] me fue referido la noche de Navidad de 1871 por un per- 
sonaje, hoy muy conocido en México, y que durante la guerra de Reforma sirvió en las filas liberales; yo no he hecho más que trasladar al papel sus palabras" (Altamirano 2017: 113). Teniendo en mente algunas implicaciones autobiográficas como las planteadas y sugeridas respectivamente por Nicole Giron en "Altamirano en Cuautla" $(28,30)$ y por América Viveros en "Altamirano: el Maestro de la República de las letras" (22-23), debo señalar primero que este final recuerda en mucho la nota explicativa firmada por el autor con la que concluye Clemencia, texto escrito y publicado por Altamirano dos años antes que La Navidad en las montañas, esto es en 1869, en las páginas del periódico El Renacimiento:

El menor de los defectos de esta pobre novelita, es que para cuento parece demasiado larga. Pero no hay que tomar formalmente la ficción de que el doctor [, el capitán, en La Navidad,] relate esto en una noche. Es un artificio literario, como otro cualquiera, pues, necesitaba yo que el doctor [, el capitán, en La Navidad,] narrara, como testigo de los hechos, y no creí que debía tener en cuenta el tamaño de la narración. Además, a pesar de mi pequeñez me amparan, para hacer perdonable lo largo del cuento, los ejemplos de Víctor Hugo en BugJargal, de Dickens en varios de sus Cuentos de Navidad, de Erckman Chatrian en sus Cuentos populares, de Enrique Zschokkle en sus Cuentos suizos, y de Hoffman en muchos de los suyos (Altamirano 1982: 92; el subrayado es mío).

"Necesitaba yo que el doctor en Clemencia — que el capitán en el caso de La Navidad en las montañas - narrara como testigo de los hechos": consciente de las posibilidades significativas de la forma, de las estructuras y recursos literarios, considero que esta aclaración de Altamirano es el quid que explica tanto el punto de vista testimonial que condiciona la exposición de la acciones, como también que otorga sentido al motivo, forma y perspectiva del viaje que vertebran composicional y estilísticamente la obra. $Y$ es que con este artificio que crea una distancia temporal entre el tiempo del enunciado y el tiempo de la enunciación, el narrador legitima ideológicamente y legendariza a nivel cultural la conciliación de los planteamientos que habían sumido al país en una guerra civil provocada por las divergencias entre liberales y conservadores durante un periodo de diez años, esto es entre 1857 y 1867. De esta manera, pues, con la perspectiva testimonial del re-conocimiento y re-conciliación que posibi- 
lita el viaje, el narrador de La Navidad en las montañas Ilega a realizar la síntesis histórica que le permite refrendar y proyectar la trascendencia del proyecto y modelo liberal de nación representado en la ficción narrativa por el "pueblecillo de montañeses hospitalarios y pobres, que vivían del producto de la agricultura y que disfrutaban de un bienestar relativo, merced a su alejamiento de los grandes centros populosos y a la bondad de sus costumbres patriarcales" (Altamirano 2017: 46), bajo la guía y ejemplo del cura del pueblo que ha "dado nuevas ideas, que se han puesto en práctica con gran provecho, y [con las que] el pueblo va saliendo poco a poco de su antigua postración" (52).

Hasta aquí este primer acercamiento al motivo y perspectiva del viaje en la poesía, los artículos costumbristas de paisajes y escenas y la novela y su incidencia en el redescubrimiento y reconfiguración discursiva, valorativa e icónica de la naturaleza, la cultura y la historia nacionales.

Luego de contextualizar y caracterizar — de matizar también_ las posibilidades cognoscitivas y éticas que Ignacio Manuel Altamirano reconoce y expone en torno al viaje como motivo y perspectiva literarios durante el siglo XIX, he intentado mostrar con la segunda parte de este trabajo cómo tales motivo y perspectiva, pese a la opinión contraria de Altamirano, se encuentran presentes en manifestaciones de los diversos géneros literarios del periodo comprendido entre 1836 y 1870 —poesía, narrativa, artículos de costumbres-, determinando sendas resoluciones éticas y estéticas del mundo, esto es la realización y valoración composicional y estilística, artística de la realidad, encaminadas a que los hablantes literarios (y con ellos los lectores) re-conocieran y re-nombraran, se apropiaran discursiva e icónicamente de la realidad natural, cultural e histórica del México independizado en 1821.

Guiado por estos planteamientos, analicé algunos poemas descriptivos que Manuel Carpio compuso en 1838, la compilación de vistas litográficas y literarias titulada México y sus alrededores. Colección de vistas monumentales, paisajes y trajes del país (1855) y la novela La Navidad en las montañas (1871), de Ignacio Manuel Altamirano. El análisis de los textos reveló como común denominador el motivo y la perspectiva del viaje 
que determina tanto la estructuración de las obras, como, más importante, el hecho de que las voces literarias (y con ellos los lectores) participaran junto con las otras manifestaciones de las bellas letras (Historia, Derecho, Filosofía, Gramática) en la configuración de un imaginario nacional, patrio, referido a la representación discursiva e icónica propia, autónoma, de la realidad física, cultural e histórica mexicana, que, rebasando la mera significación política, hiciera posible la emancipación mental, cultural de México y el mexicano.

El desarrollo posterior de la historia de la cultura y de la historia de la cultura literaria de México muestra que el objetivo del motivo y perspectiva del viaje se cumplió. La lectura asidua, la popularidad de la poesía de Carpio todavía durante las postrimerías del afrancesado porfiriato, la vigencia utópica y conciliadora de La Navidad en las montañas, de Ignacio Manuel Altamirano, y, también, la presencia y validez nacionalista y patriótica actual de la parte plástica de los cuadros de paisajes y escenas costumbristas del siglo XIX (en demérito de la parte literaria, desafortunadamente), revelan que el viaje en la tradición literaria mexicana decimonona articuló sendos entramados que redescubrieron y renombraron discursiva e icónicamente a la realidad mexicana, permitiéndole alcanzar así la representatividad nacional y trascendencia entre el concierto de las naciones y culturas.

\section{Bibliografía}

Aguilar Ochoa, Arturo. "Los inicios de la litografía en México. El periodo oscuro (1827-1837)", en Anales del Instituto de Investigaciones Estéticas. XXIX-90 (2007): 65-100.

Altamirano, Ignacio Manuel. Clemencia. México: Editores Mexicanos Unidos, 1982.

AltamiRano, Ignacio Manuel. "Introducción al Viaje a Oriente, de Luis Malanco", en Obras completas. Escritos de literatura y arte. t. 2. México: Secretaría de Educación Pública, 1988.

Altamirano, Ignacio Manuel. La Navidad en las montañas. El Zarco. México: Penguin, 2017.

Bajtín, Mıjaíl. Teoría y estética de la novela. Trad. Helena Kriukova y Vicente Cazcarra. Madrid: Taurus, 1988. 
Bobadilla Encinas, Gerardo Francisco. Literatura y cultura mexicana del siglo XIX. Lecturas y relecturas críticas e historiográficas. México: Universidad de Sonora, 2013.

BRADING, David. Los orígenes del nacionalismo mexicano. Trad. Soledad Loaeza Grave. México: Era, 1998.

Carpio, Manuel. Poesías, con una biografía escrita por el señor don José Bernardo Couto. México: Imprenta de Andrade y Escalante, 1860.

Carrizo Rueda, Sofía. "Estudio preliminar. Construcción y recepción de 'fragmentos del mundo'", en Escrituras del viaje. Construcción y recepción de "fragmentos del mundo". Buenos Aires: Biblos, 2008. 9-33.

Díaz ArCiniega, Víctor. "Presentación a 'Utilidad de la literatura en México', de Luis de la Rosa", en Jorge Ruedas de la Serna. La misión del escritor. Ensayos mexicanos del siglo XIx. México: Universidad Nacional Autónoma de México. Coordinación de Humanidades, 1996. 81-84 (col. Ida y regreso al siglo XIX).

Díaz Covarrubias, Juan. Gil Gómez el insurgente o la hija del médico. México: Porrúa, 1991.

Giron, Nicole. "Altamirano en Cuautla", en Homenaje a Ignacio Manuel Altamirano (1834-1893). Manuel Sol Tlachi y Alejandro Higashi (eds.). Xalapa: Universidad Veracruzana, 1997. 21-48.

LuKÁCs, GeORG. La novela histórica. México: Grijalbo, 1957.

Martínez, José Luis. La emancipación literaria de México. México: Antigua Librería Robredo, 1955.

Mauleón, HéCtOr De. "La ciudad de los palacios", en Nexos (24 de abril de 2015). Artículo en línea disponible en: <https://www.nexos.com.mx/?p=24691>.

México y sus alrededores. Colección de vistas monumentales, paisajes y trajes del país. México: Establecimiento Litográfico de Decaén, 1855.

MORA, PABlO. "Manuel Carpio, poeta entre ruinas", en Literatura Mexicana. XI-1 (2000): 61-77.

Pacheco, José Emilıo (selección y prólogo). Poesía mexicana. Siglos xix y xx. México: Promexa, 1992.

Pérez Salas, María Esther. Costumbrismo y litografía en México: un nuevo modo de ver. México: Universidad Nacional Autónoma de México, 2005.

QUIRARTE, VICENTE (edición, selección y prólogo). Republicanos en otro imperio. Viajeros mexicanos a Nueva York (1830-1895). México: Universidad Nacional Autónoma de México, 2009.

Rubial García, Antonio. El paraíso de los elegidos. Una lectura de la historia cultural de Nueva España (1521-1804). México: Fondo de Cultura Económica / Universidad Nacional Autónoma de México, 2010.

Ruedas de la Serna, JORGe (coordinador). La misión del escritor. Ensayos mexicanos del siglo XIX. México: Universidad Nacional Autónoma de México. Coordinación de Humanidades, 1996 (col. Ida y regreso al siglo XIX).

TEIXIDOR, FELIPE (compilación y prólogo). Viajeros mexicanos (siglos XIX y XX). México: Porrúa, 2002.

Toussaint, Manuel. La litografía en México en el siglo XiX. México: Estudios Neolitho, 1934. 
Treviño, Blanca Estela. "Presentación a 'Carácter y objeto de la literatura', de José María Lafragua", en Jorge Ruedas de la Serna. La misión del escritor. Ensayos mexicanos del siglo xIx. México: Universidad Nacional Autónoma de México. Coordinación de Humanidades, 1996. 63-65 (col. Ida y regreso al siglo XIX).

Viveros Anaya, Luz América. "Prólogo. Altamirano: el Maestro de la república de las letras", en Ignacio Manuel Altamirano. La Navidad en las montañas y El Zarco. México: Penguin, 2017. 9-34

Zarco, Francisco. "La fuente de Salto del agua", en México y sus alrededores. Colección de vistas monumentales, paisajes y trajes del país. México: Establecimiento Litográfico de Decaén, 1855. 4-6.

Crédito de las imágenes

Las estampas y las litografías que aparecen en este artículo han sido tomadas de las publicaciones:

El Álbum Mexicano, t. I. México: Imprenta de Ignacio Cumplido, 1849.

El Museo Mexicano ó Miscelánea pintoresca de amenidades curiosas e instructivas, t. III. México: Imprenta de Ignacio Cumplido, 1844.

México y sus alrededores. Colección de vistas monumentales, paisajes y trajes del país. México: Establecimiento litográfico de Decaén, 1855.

\section{Gerardo Francisco Bobadilla Encinas}

Es maestro de la Licenciatura en Literaturas Hispánicas de la Universidad de Sonora. Desarrolla las líneas de investigación referidas a "Relaciones historia-literatura" e "Historia de la novela en México", a las que están asociadas sus participaciones en congresos y publicaciones de la especialidad. Entre otros, ha publicado individualmente textos como Literatura y cultura mexicana del siglo XIX (2013), Emancipación y literatura en México (2012) y Estudios de literatura mexicana. Lecturas críticas y replanteamientos historiográficos (2009). Ha dirigido la publicación de volúmenes colectivos como A cien años de Los de abajo, de Mariano Azuela (2016), Independencia y literatura en México (2011), Lecturas y relecturas de La región más transparente (2008). 